Received 27 May 2020 Accepted 5 February 2021

Link to DOI:

10.25220/WNJ.V05.i1.0004

Journal Website: www.worldnutrijournal.org

\title{
Resuscitation fluid requirements in burn injury patients using intravenous vitamin C: An evidence-based case report
}

\author{
Hendra, ${ }^{1}$ Davie Muhammad, ${ }^{1}$ Diyah Eka Andayani ${ }^{1}$ \\ 1. Department of Nutrition, Faculty of Medicine, Universitas Indonesia, Dr. Cipto Mangunkusumo \\ Hospital, Jakarta, Indonesia
}

\begin{abstract}
Background: Based on the Guideline of European Society for Clinical Nutrition and Metabolism (ESPEN) in 2013, vitamin C is an additional therapy for burn patients during the resuscitation process and reduce the amount of fluid resuscitation but still needs further evidence. This study aims to find the effect of intravenous vitamin $C$ administration to reduce the fluid requirements during first 24 hours resuscitation in burn patients.

Methods: Electronic Literature search were performed in PubMed, Cochrane, Scopus and ProQuest databases. Hand searching was also performed. MesH Term was used in PubMed database searching. All literature obtained was screened based on inclusion and exclusion criteria.

Results: Three articles were selected based on the eligibility criteria. Two Randomized Controlled Trial / RCT studies concluded that intravenous vitamin C administration reduced resuscitation fluid requirements in burn patients. But in the case control study there was no significant difference in resuscitation fluid requirements between the two groups. Other study reported that there were significant differences in resuscitation fluid requirements between the two groups. Both RCT studies did not use the blinding method and explained the side effects of therapy. A case control study reported an increase in cases of acute kidney failure in the vitamin $\mathrm{C}$ group compared to control (23\% vs $7 \%$ ) although it was not statistically significant.

Conclusions: Intravenous vitamin C can reduce the resuscitation fluid requirements in the first 24 hours in burn patients (grade $\mathrm{C}$ recommendation).

Keywords burns, vitamin C, ascorbic acid, resuscitation, fluid requirements
\end{abstract}

\section{Introduction}

Based on data from Dr. Cipto Mangunkusumo Hospital, $72.2 \%$ of patients treated at burn center were aged $\geq 15$ years. Most of adult patients $(73.9 \%)$ suffered third degree burns with $11-30 \%$ of TBSA. In 2015 , the length of stay of patients with burns $\leq$ $40 \%$ of TBSA was 15 days (1-66 days) with the mortality of all patients reaching $27.7 \% .^{1}$ The study also showed an increase in mortality of burn patients

\section{Corresponding author:}

dr. Diyah Eka Andayani, MGizi, SpGK

Department of Nutrition, Faculty of Medicine, Universitas

Indonesia

Jl. Salemba Raya no.6, Central Jakarta, Indonesia

Email:d_eka_gz@yahoo.com in Dr. Cipto Mangunkusumo General Hospital from 2013 to 2015, meanwhile according to the results of a systematic review there is a tendency of decreasing mortality in burn patients in various countries. ${ }^{1,2}$

According to Australian and New Zealand Burn Association, the first aid in burn treatments include fluids, analgesics, tests and tubes. Fluid resuscitation is the most important in the treatment of burns. Urine production is monitored every hour to find out the adequacy of fluid resuscitation. Adjustment of fluid resuscitation volume can also be done as indicated. ${ }^{3}$

The administration of resuscitation which exceeded expected volume could harm the burn patients. Fluid excess of $25 \%$ of predicted volume increased the risk of pneumonia, acute respiratory distress syndrome, multiple organ failure, 
bloodstream infections, and death. ${ }^{4}$ This condition was called "fluid creep". 5

Vitamin C is an essential micronutrient in our body. One of its benefits is to strengthen blood vessel endothelium. One study found that the mechanism of vitamin $\mathrm{C}$ reduces the permeability of blood vessels is through increasing Epac1 protein that binds to cell microtubules and increases its stability. ${ }^{6}$ In addition, vitamin $\mathrm{C}$ also has a role in reducing histamine which will reduce vascular permeability. ${ }^{7}$ Based on ESPEN guidelines, vitamin C requirements is increased during the acute phase of burns $(0.5-1 \mathrm{~g} /$ day $){ }^{8}$

According to research conducted by Tanaka $\mathrm{H}$ et $a l,{ }^{9}$ vitamin $\mathrm{C}$ is needed to reduce capillary leakage and reduce fluid requirements in burn patients where the fluid needs go down by about $45.5 \%(\mathrm{p}<0.004)$. However, a different result is stated by Nakajima $M$ et al that there is an increase in fluid requirements after administering $10 \mathrm{~g} /$ day vitamin $\mathrm{C}$ intravenously and do not reduce the fluid requirements with a dose above $24 \mathrm{~g} /$ day. ${ }^{10}$ Based on this information, it is interesting to know the effect of intravenous vitamin $\mathrm{C}$ to decrease the fluid requirements in burn resuscitation.

\section{Clinical scenario and question}

A 22 years old male patient came to Emergency Room (ER) with burns on his face, body, both arms and both legs in the last 10 hours before being admitted to the hospital. His motorcycle crashed petrol kiosk and suddenly the fire appeared and burned his body. The patient was taken to the nearest hospital for emergency treatment. A total of 3000 $\mathrm{mL}$ fluid resuscitation was administered. Patients were referred to Dr. Cipto Mangunkusumo General Hospital for further treatment.

At the ER, the patient had no complaints due to inhalation trauma. The examination showed compos mentis with normal vital signs and grade II-III burns $31 \%$ of Total Body Surface Area (TBSA). The fluid resuscitation was given according to Baxter's formula with a total fluid requirement of $5580 \mathrm{~mL}$ so that it still had to be continued with resuscitation of $2580 \mathrm{~mL} / 14$ hours. Patients were given pain medication and a urine catheter was placed with the initial urine $1300 \mathrm{~mL} / 10$ hours $(2.8 \mathrm{~mL} / \mathrm{kg} /$ hour $)$. During 14 hours of fluid resuscitation, the amount of urine production was $3 \mathrm{~mL} / \mathrm{kg} /$ hour. Patients was not given other supporting therapies for resuscitation such as vitamin $\mathrm{C}$.

Based on the Guideline European Society for Clinical Nutrition and Metabolism (ESPEN) in 2013, vitamin $C$ is an additional therapy for burn patients during resuscitation which is known to have antioxidant mechanisms and reduce vascular permeability so that the fluid requirements will decrease. However, this therapy still requires further research and validation regarding its effectiveness.

The subjects in this study were patients with burns whose outcome was assessed as the need for fluid resuscitation after giving intravenous vitamin C. Therefore the clinical question is "Does the administration of intravenous vitamin $\mathrm{C}$ during fluid resuscitation in the first 24 hours reduce the need for fluid resuscitation in burn patients?"

\section{Methods}

Literature search was performed using advanced searching on PubMed, Cochrane, Scopus, and ProQuest on February 24, 2020. MeSH term was used in PubMed database search. The keywords used are "burn", "ascorbic acid", and "resuscitation". The author also performed hand searching method. Duplicated articles were filtered with Endnote program. The title and abstract are screened with eligibility criteria. The critical appraisal was done based on the agreement of three authors.

The inclusion criteria were: 1) The RCT, cohort and case control study, 2) Research carried out on humans, 3) Subjects were burn patients aged $>15$ years, 4) Subjects had the characteristics of burn area $>20 \%$ or burn index $\geq 15,5$ ) Used intravenous vitamin $\mathrm{C}$ during burn resuscitation. The exclusion criteria were: 1) Research full text was unavailable and 2) Review articles.

\section{Results}

Electronic literature searching method was carried out on 4 databases namely PubMed, Cochrane, Scopus and ProQuest using the keywords "burn", "ascorbic acid", "resuscitation". There were 4 literature found in PubMed database, 4 literature from Cochrane Library database, 77 literature from Scopus database, 216 literature from ProQuest 
database, and no additional literature was found from handsearching method (Table 1). From all literature obtained, 4 literature met the eligibility criteria, i.e. 3 literature from PubMed database and 1 literature from ProQuest database (Figure 1).

Table 2 shows the study characteristics of the papers. Table 3 shows the validity criteria. Table 4 shows similarity with the PICO (problems, interventions, controls, outcomes).

\section{Discussion}

Tanaka et $\mathrm{al}^{9}$ conducted a Randomized Control Trial (RCT) study to determine the effect of intravenous vitamin $\mathrm{C}$ administration on the requirement of fluid resuscitation in burn patients. The results of the study are, there is a statistically significant difference between the group with intravenous vitamin $\mathrm{C}$ and the group without intravenous vitamin $C \quad(p<0.05)$, where the group with intravenous vitamin $C$ requires lower resuscitation fluids than the group without intravenous vitamin $\mathrm{C}$ administration. The strength of this study is the RCT design with the evidence level 2B. Unfortunately, there were the relatively small number of patients included in the study and the authors did not mention about concealed randomization of the subjects.

Qin et $\mathrm{al}^{11}$ conducted an RCT design and stated that there was a statistically significant difference in the effect of intravenous vitamin $\mathrm{C}$ on the decrease in fluid resuscitation requirements $(p<0.05)$. The weaknesses are the research did not explain in detail the difference in the average resuscitation fluid given and did not provide confidence interval of the result.

Tanaka et al and Qin et al research did not do blinding and explain who and how they gave fluid therapy in detail. In addition, this study also did not mention who assessed the amount of fluid needed. This can lead to research bias.

Lin $\mathrm{J}$ et $\mathrm{al}^{12}$ conducted a case control study. The results of this study is no significant difference in the need for resuscitation fluids after intravenous vitamin $\mathrm{C}$ was given $(\mathrm{p}=0.6)$. The weakness of this study is case control study design with level of evidence $3 \mathrm{~B}$, so it cannot be a good reference for application in the therapy.

Kahn SA et al $^{13}$ conducted a retrospective review study. This study concludes that the administration of vitamin $\mathrm{C}$ can reduce the need for resuscitation fluids by up to $25 \%$ and is statistically significant. However, with a retrospective design and level of evidence $3 \mathrm{~B}$, this study is not suitable to be applied in the therapy.

All studies did not explain the side effects of intravenous vitamin $\mathrm{C}$ during resuscitation, but Lin $\mathrm{J}$ et al reported higher cases of acute kidney failure in the group given high vitamin $\mathrm{C}$ compared to controls $(23 \%$ vs $7 \%, \mathrm{p}=0.06) .{ }^{12} \mathrm{Kahn}$ SA et al reported that there were no differences in cases of kidney failure in the intervention and control groups. ${ }^{13}$ Further research is needed regarding the side effects of intravenous vitamin $\mathrm{C}$ administration.

Research evidence regarding the effectiveness and safety of using vitamin $\mathrm{C}$ during resuscitation of burn patients is still very limited (only 2 RCTs in 20 years, 1 case control, 1 retrospective review). Based on our literature search, there were 2 studies (2006 and 2017) that were registered at ClinicalTrial.gov regarding the administration of vitamin $\mathrm{C}$ in burn patients (NCT00350077 and NCT01587261). However, the study was withdrawn by reason of lack of evidence and was not approved by the FDA. ${ }^{14,15}$

After evaluating the literature and the evidence obtained, the authors conclude that the overall level of recommendation for intravenous vitamin $\mathrm{C}$ in reducing the amount of fluid resuscitation for burn patients is grade $\mathbf{C}$ because two literature have $2 \mathrm{~B}$ level of evidence and two literature with 3B level of evidence with different results.

Sensitivity analysis cannot be conducted in this EBCR because all of the studies do not provide confidence interval. The study about vitamin $\mathrm{C}$ administration during fluid resuscitation in burn injury was scarce. It contributes to our limitation in concluding the evidence.

\section{Conclusion}

The authors conclude that in this case, administration of intravenous vitamin $\mathrm{C}$ can reduce the need for fluid resuscitation in the first 24 hours of burn patients with grade $\mathrm{C}$ recommendations. There are no clear guidelines regarding the dosage of intravenous vitamin $\mathrm{C}$ for burn resuscitation as well as the importance of evaluating the safety of intravenous vitamin C. Studies with a larger number 
of patients with better methods are needed to support these conclusions and recommendations.

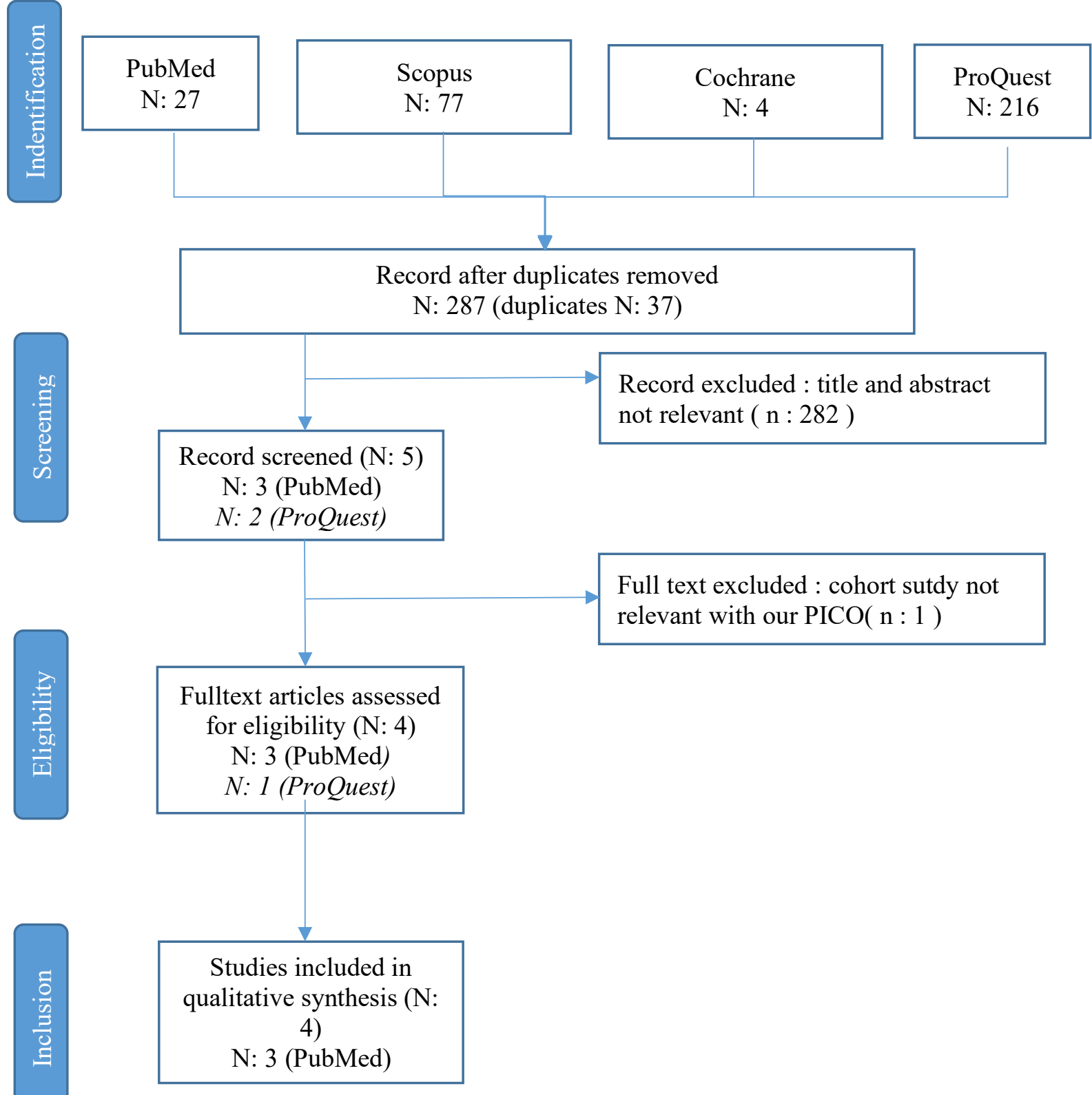

Figure 1. Prisma's flow chart 
Table 1. Resources \& search strategy

\begin{tabular}{|c|c|c|c|}
\hline Database & Search Strategy & Hits & Selected article \\
\hline PubMed & $\begin{array}{l}(((\text { ascorbic acid[MeSH Terms]) OR ascorbic acid[Title/Abstract])) AND } \\
((\text { burn[MeSH Terms] }) \text { OR burn[Title/Abstract])) AND ((resuscitation[MeSH Terms]) } \\
\text { OR resuscitation[Title/Abstract]) }\end{array}$ & 27 & 3 \\
\hline Cochrane Library & $\begin{array}{lll}\# 1 & \text { "Burn" } & \mathrm{N}: 4103 \\
\# 2 & \text { "Ascorbic acid" } & \mathrm{N}: 3768 \\
\# 3 & \text { "Resuscitation" } & \mathrm{N}: 8280 \\
\# 1 & \text { AND \#2 AND \#3 } & \mathrm{N}: 4\end{array}$ & 4 & 0 \\
\hline Scopus & $\begin{array}{l}\text { ( TITLE-ABS-KEY ( burn ) AND TITLE-ABS-KEY ( ascorbic AND acid) AND } \\
\text { TITLE-ABS-KEY ( resuscitation ) ) }\end{array}$ & 77 & 0 \\
\hline ProQuest & Burn AND ascorbic acid AND resuscitation & 216 & 1 \\
\hline
\end{tabular}

\section{Table 2. Study characteristics}

\begin{tabular}{|c|c|c|c|c|}
\hline Author & Patient group & Outcome & Key Result & Comment \\
\hline $\begin{array}{l}\text { Tanaka H et al, } \\
(2000) \\
\text { Arch Surg, } \\
\text { Japan } 7 \\
\text { RCT (level 2B) }\end{array}$ & $\begin{array}{l}\text { Burn patient more than } 30 \% \text { TBSA from } 1 \\
\text { December } 1992-31 \text { December } 1997 \text {, } \\
\text { randomized to } 2 \text { groups } \\
\text { Group 1: vitamin C } 66 \mathrm{mg} / \mathrm{kg} / \mathrm{h} \text { in the first } \\
24 \text { hours was given } \\
\text { Group 2: control group, without vitamin C. } \\
\text { Total }(\mathrm{n}=37 \text { ) }\end{array}$ & $\begin{array}{l}\text { Fluid requirement in } \\
24 \text { hours } \\
\text { adjusted according to } \\
\text { urine output }\end{array}$ & $\begin{array}{l}\text { Total fluid in } 24 \text { hours in Group } 2 \text { was } 5,5 \pm \\
3,1 \mathrm{ml} / \mathrm{kg} / \% \mathrm{TBSA} \text {, whereas in group } \\
1 \text { was } 3.0 \pm 1.7 \mathrm{ml} / \mathrm{kg} / \% \text { TBSA }(\mathrm{p}<0.05 \text { ). } \\
\text { The reduction of fluid requirement was } 45.5 \\
\%\end{array}$ & $\begin{array}{l}\text { This research concluded that } \\
\text { intravenous vitamin C could } \\
\text { significantly reduce fluid requirement } \\
\text { during resuscitation }\end{array}$ \\
\hline $\begin{array}{l}\text { Qin FJ, et al, } \\
(2019) \\
\text { Drug Des } \\
\text { Devel Ther, } \\
\text { China } \\
\text { RCT (level 2B) }\end{array}$ & $\begin{array}{l}\text { Burn patient with more than } 30 \% \text { TBSA } \\
\text { from July } 2011 \text { to September } 2016 \\
\text { Group A: intravenous Tiopronin } \\
\text { mg/kg/day) + standard therapy } \\
\text { Group B: intravenous vitamin C } \\
(792 / \mathrm{kg} / \text { day }+ \text { standard therapy } \\
\text { Group C: Standard therapy with Evans } \\
\text { formula, nutritional support, intravenous } \\
\text { and topical antibiotics, etc. } \\
\text { Total }(\mathrm{n}=36)\end{array}$ & $\begin{array}{l}\text { Fluid requirement in } \\
24 \text { hours } \\
\text { adjusted according to } \\
\text { urine output }\end{array}$ & $\begin{array}{l}\text { Fluid resuscitation requirement in group } \mathrm{A} \\
\text { and B reduce than group } \mathrm{C}(\mathrm{p}<0,05) \\
\text { Group A: TBSA } \% \times \text { body weight }(\mathrm{kg}) \times 1.46 \\
\mathrm{~mL}(\text { colloid to electrolyte ratio } 1: 2)+\text { water } \\
2000 \mathrm{~mL} \\
\text { Group B: TBSA } \% \times \text { body weight }(\mathrm{kg}) \times 1.48 \\
\mathrm{~mL}(\text { colloid to electrolyte ration } 1: 2)+ \\
\text { water } 2000 \mathrm{~mL} \\
\text { Group } \mathrm{C}: \text { TBSA } \% \times \text { body } \\
\text { weight }(\mathrm{kg}) \times 1.64 \mathrm{~mL}(\text { colloid to } \\
\text { electrolyte ration } 1: 2)+ \text { water } 2000 \mathrm{ml} \text {. }\end{array}$ & $\begin{array}{l}\text { This research concluded that } \\
\text { intravenous vitamin C could } \\
\text { significantly reduce fluid requirement } \\
\text { during resuscitation }\end{array}$ \\
\hline
\end{tabular}


Table 2. Study characteristics (continued)

\begin{tabular}{|c|c|c|c|c|}
\hline Author & Patient group & Outcome & Key Result & Comment \\
\hline $\begin{array}{l}\text { Lin J,et al, } \\
(2018) \\
\text { J Burn Care } \\
\text { Res, USA }{ }^{10} \\
\text { Case control } \\
(\text { level 3B) }\end{array}$ & $\begin{array}{l}\text { Burn patients from } 2013-2015 \text {, divided into } \\
\text { case group and control group, age and } \\
\text { percentage of TBSA were matched } \\
( \pm 5 \text { years and } \pm 5 \% \text {, respectively) } \\
\text { Group 1: intravenous vitamin C } \\
(66 \mathrm{mg} / \mathrm{kg} / \mathrm{h}) \text { during resuscitation } \\
(\mathrm{n}=38) \\
\text { Group 2: without intravenous vitamin C. } \\
(\mathrm{n}=42) \\
\text { Total }(\mathrm{n}=80)\end{array}$ & $\begin{array}{l}\text { Fluid requirement in } \\
24 \text { hours } \\
\text { adjusted according to } \\
\text { urine output }\end{array}$ & $\begin{array}{l}\text { No difference in total fluid } \\
\text { administration } \\
(4.6 \pm 2.6 \mathrm{ml} / \mathrm{kg} / \% \text { TBSA and } 4.3 \pm 2.5 \\
\mathrm{ml} / \mathrm{kg} / \% \mathrm{TBSA})(\mathrm{p}=0.6)\end{array}$ & $\begin{array}{l}\text { This research concluded that } \\
\text { intravenous vitamin } \mathrm{C} \text { could not } \\
\text { significantly reduce fluid requirement } \\
\text { during resuscitation }\end{array}$ \\
\hline $\begin{array}{l}\text { Kahn SA, et al, } \\
(2011) \text { J Burn } \\
\text { Care Res, } \\
\text { USA }^{11} \\
\text { Retrospective } \\
\text { Review } \\
\text { (level 3B) }\end{array}$ & $\begin{array}{l}\text { Burn patients } \\
\text { Group 1: intravenous } \\
\text { vitamin } \mathrm{C}(\mathrm{n}=17) \\
\text { Group 2: without vitamin C } \\
\text { (cristaloid only) } \\
(\mathrm{n}=16) \\
\text { Total }(\mathrm{n}=33)\end{array}$ & $\begin{array}{l}\text { Fluid requirement in } \\
24 \text { hours } \\
\text { adjusted according to } \\
\text { urine output }\end{array}$ & $\begin{array}{l}\text { Vitamin } \mathrm{C}: 5.3 \pm 1 \mathrm{ml} / \mathrm{kg} / \% \text { TBSA } \\
\text { Control }: 7.1 \pm 1 \mathrm{ml} / \mathrm{kg} / \% \text { TBSA } \\
\text { The reduction of fluid requirement was } 25 \\
\%(p<0.05)\end{array}$ & $\begin{array}{l}\text { This research concluded } \\
\text { that intravenous vitamin } \mathrm{C} \text { could } \\
\text { significantly reduce fluid requirement } \\
\text { during resuscitation }\end{array}$ \\
\hline
\end{tabular}

Table 3. Validity criteria

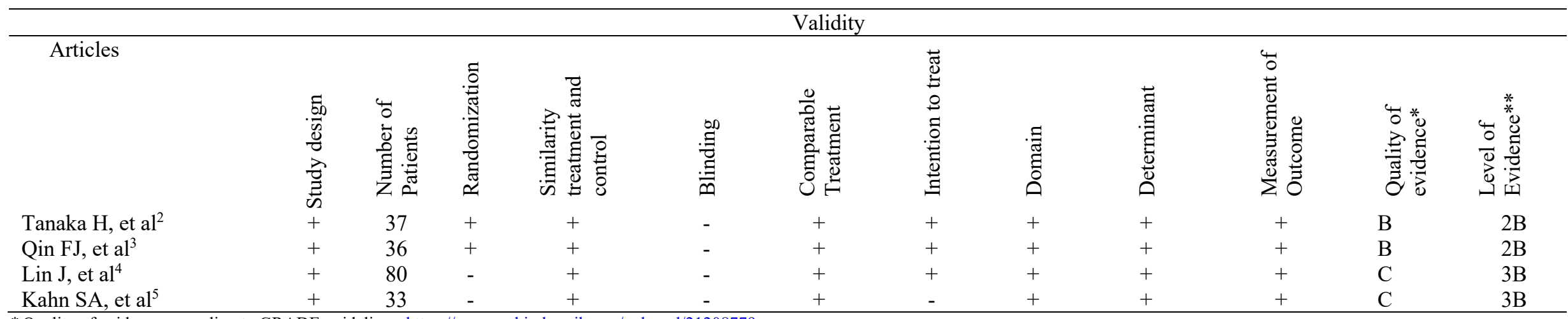

* Quality of evidence according to GRADE guidelines, https://www.ncbi.nlm.nih.gov/pubmed/21208779

**Level of evidence according to Oxford Center of Evidence-based Medicine (CEBM), http://www.cebm.net.

+ clearly mentioned in the article; - not done; ? Not stated clearly; B (Moderate) : We are moderately confident in the effect estimate: The true effect is likely to be close to the estimate of the effect, but there is a possibility that it is substantially different; $\mathrm{C}($ Low $)$ : Our confidence in the effect estimate is limited: The true effect may be substantially different from the estimate of the effect. 
Table 4. Similarity with PICO

\begin{tabular}{cccc}
\hline & Similarity Population & Similarity Determinant & Similarity Outcome \\
\hline Tanaka H et al. & + & + & + \\
Qin FJ, et al. & + & + & + \\
Lin J,et al. ${ }^{10}$ & + & + & + \\
Kahn SA, et al. $^{11}$ & + & + & + \\
\hline
\end{tabular}

\section{Conflict of Interest}

Authors declared no conflict of interest regarding this article.

\section{Open Access}

This article is distributed under the terms of the Creative Commons Attribution 4.0 International Licence

(http://creativecommons.org/licenses/by/4.0/), which permits unrestricted use, distribution, and reproduction in any medium, provided you give appropriate credit to the original author(s) and the source, provide a link to the Creative Commons license, and indicate if changes were made.

\section{References}

1. Wardhana A, Basuki A, Prameswara ADH, Rizkita DN, Andarie AA, Canintika AF. The epidemiology of burns in Indonesia's national referral burn center from 2013 to 2015. Burns Open. 2017;1:67-73.

2. Smolle C, Cambiaso-daniel J, Forbes AA, Wurzer P, Branski LK, Huss F, et al. Recent trends in burn epidemiology worldwide: A systematic review. 2018;43:249-57.

3. Cheri T. Emergency management of severe burns (EMSB). Albany creek: ANZBA; 2013.

4. Klein MB, Hayden D, Elson C, Nathens AB, Gamelli RL, Gibran NS, et al. The association between fluid administration and outcome following major burn: A multicenter study. Ann Surg. 2007;245:622-8.

5. Saffle JR. The phenomenon of "fluid creep" in acute burn resuscitation. J Burn Care Res. 2007;28:382-95.

6. Parker WH, Rhea EM, Qu ZC, Hecker MR, May JM. Intracellular ascorbate tightens the endothelial permeability barrier through Epac1 and the tubulin cytoskeleton. Am J Physiol - Cell Physiol. 2016;311:C652-62.

7. Hagel AF, Layritz CM, Hagel WH, Hagel HJ, Hagel E, Dauth $\mathrm{W}$, et al. Intravenous infusion of ascorbic acid decreases serum histamine concentrations in patients with allergic and non-allergic diseases. Naunyn Schmiedebergs Arch Pharmacol. 2013;386:789-93.

8. Rousseau AF, Losser MR, Ichai C, Berger MM. ESPEN endorsed recommendations: Nutritional therapy in major burns. Clin Nutr. 2013;32:497-502.

9. Tanaka H, Matsuda T, Miyagantani Y, Yukioka T, Matsuda H, Shimazaki S. Reduction of resuscitation fluid volumes in severely burned patients using ascorbic acid administration: A randomized, prospective study. Arch Surg. 2000;135:326-31.

10. Nakajima M, Kojiro M, Aso S, Matsui H, Fushimi K, Kaita Y, et al. Effect of high-dose vitamin $\mathrm{C}$ therapy on severe burn patients: A nationwide cohort study. Crit Care. 2019;23:1-8.

11. Qin FJ, Hu XH, Chen Z, Chen X, Shen YM. Protective effects of tiopronin against oxidative stress in severely burned patients. Drug Des Devel Ther. 2019;13:282732.

12. Lin J, Falwell S, Greenhalgh D, Palmieri T, Sen S. High-dose ascorbic acid for burn shock resuscitation may not improve outcomes. J Burn Care Res. 2018;39:708-12.

13. Kahn SA, Beers RJ, Lentz CW. Resuscitation after severe burn injury using high-dose ascorbic acid: A retrospective review. J Burn Care Res. 2011;32:110-7.

14. ClinicalTrial.gov [Internet]. Bethesda (MD): National Library of Medicine (US). 2011 Dec 20-Indentifier NCT00350077, The Effect of High Dose Vitamin C in Burn Patients; 2006 Jul 10 [cited 2020 Feb 29]; [about 5 screens]. Available from: https://clinicaltrials.gov/ct2/show/NCT00350077

15. ClinicalTrial.gov [Internet]. Bethesda (MD): National Library of Medicine (US). 2019 Mar 6- . Indentifier NCT01587261, Vitamin C for Severe Thermal Injuries; 2012 Apr 30 [cited 2020 Feb 29]; [about 5 screens]. Available from: https://clinicaltrials.gov/ct2/show/ NCT01587261 